Part of Bureau of Standards Journal of Research, vol. 12, April 1934

\title{
THERMAL EXPANSIONS OF SOME SODA-LIME-SILICA GLASSES AS FUNCTIONS OF THE COMPOSITION
}

\author{
By B. C. Schmid, A. N. Finn, and J. C. Young
}

ABSTRACT

The linear thermal expansions from $25 \mathrm{C}$ to the "critical" and "softening" temperatures were determined for 19 soda-silica and 30 soda-lime-silica glasses by the interferometer method. Graphs have been prepared from which the critical termperature, softening temperature, the expansions to these temperatures, and the annealing range can be predicted approximately for any glass in the range of compositions studied.

I. Introduction

II. Method used.

III. Data obtained and results._.

IV. Reproducibility and accuracy of results_.

V. Annealing range.

VI. Summary

\section{INTRODUCTION}

This report is the third of a series of studies on the relation between chemical composition and properties of some soda-lime-silica glasses. In the first report, relating to index of refraction, ${ }^{1}$ the purpose of the general study was given, the method of making the glasses was detailed, essential parts of the methods of chemical analyses were outlined, and the character of annealing was described. The second report contained the results obtained with respect to density, ${ }^{2}$ and the present paper gives the results obtained by measuring the thermal expansion of 37 of the glasses used in the previous studies and 12 additional glasses made especially for the current study. Of the total number 19 were soda-silica and 30 were soda-lime-silica glasses, the composition varying so that the former contained approximately from 17 to 50 percent soda and the latter from 3 to 20 percent lime.

The linear thermal expansion of each glass from 25 to $400 \mathrm{C}$, to the critical temperature, and to the softening temperature, and also these critical and softening temperatures are included in the data presented.

1 Faick, C. A., and Finn, A. N., The index of refraction of some soda-lime-silica glasses as a function of the composition, B.S. Jour. Research, vol. 6 (RP320), p. 993, June 1931; also Jour. Am. Cer. Soc., vol. 14, no. 7, p. 518,1931 .

2 Glaze, F. W., Young, J. C., and Finn, A. N., The density of some soda-lime-silica glasses as a function of the composition, B.S. Jour. Research, vol. 9 (RP507), p. 799, Dec. 1932. 


\section{METHOD USED}

Expansion measurements were made by the interferometer method described by Peters and Cragoe, ${ }^{3}$ which consists essentially of placing three small truncated cones of glass about $5 \mathrm{~mm}$ high between two optically flat fused-quartz disks and counting the number of interference fringes which pass a reference point in the viewing apparatus as the temperature of the furnace is raised at a rate of approximately $3^{\circ} \mathrm{C}$ per minute.

Expansion measurements were made in duplicate on all the sodalime-silica glasses, and the second measurements were regarded as the more satisfactory because such measurements were, in general, more nearly reproducible than those obtained in the first test. In all cases of duplication the data reported are from the second test. Because of the unstable (hygroscopic) nature of most of the sodasilica glasses and the consequent difficulty in handling them, their expansions were in many cases measured only once and the data, except for a few of the more stable glasses, are based on single tests.

\section{DATA OBTAINED AND RESULTS}

The composition of each glass, the expansion from 25 to $400 \mathrm{C}$, the critical temperature, the expansion from $25 \mathrm{C}$ to the critical temperature, the softening temperature, and the corresponding expansion are given in table 1 . The viscous deformability of a glass increases rapidly between the so-called critical and softening temperatures. At the critical temperature the rate of deformation is too low to result in measurable deformations under the conditions of operation in these expansion tests; as the softening temperature is approached, however, the rate of deformation becomes so great that it results in a fairly rapid and measurable flattening of the bearing points of the test specimen under the weight of the interferometer plate. When determined under the same experimental conditions, these temperatures are rather characteristic of a given glass and it is presumed also that under such conditions they give a fairly good method of showing at what temperatures different glasses reach comparable deformabilities.

The critical temperature, or the temperature at which the rate of expansion definitely increases, was regarded as the temperature at which a straight line drawn through four or five consecutive points on the expansion-temperature curve departed definitely from a line drawn through the next higher points.

The softening temperature for any glass was relatively easily determined because, for the purpose of this paper, it was regarded as the temperature at which the glass became so soft that its rate of shortening by deformation was equal to its rate of expansion and the movement of the interference fringes practically ceased. This point was followed by a reversal in the direction of movement of the fringes, caused by increasing deformation of the specimens.

Since the temperature at which expansion measurements were started varied between 25 and 39 C, all expansions were "corrected" to $25 \mathrm{C}$ as a starting point. This extrapolation was made on the assumption that the rate of expansion between 100 and $200 \mathrm{C}$ is

${ }^{3}$ B.S. Scientific Papers, vol. 16 (S393), p. 449, 1920. See also Merritt, G. E., B.S. Jour. Research, vol. 10 (RP515), p. 59, 1933. 
TABLE 1.-Compositions, observed critical and softening temperatures, and linear thermal expansions between the indicated temperatures

\begin{tabular}{|c|c|c|c|c|c|c|c|c|}
\hline \multirow{2}{*}{$\begin{array}{c}\text { Glass } \\
\text { number }{ }^{1}\end{array}$} & \multicolumn{3}{|c|}{ Composition ${ }^{2}$} & \multirow{2}{*}{$\begin{array}{l}\text { Expan- } \\
\text { sion }^{3}(25 \\
\text { to } 400 \mathrm{C})\end{array}$} & \multirow{2}{*}{$\begin{array}{l}\text { Critical tem- } \\
\text { perature }^{3}\end{array}$} & \multirow{2}{*}{$\begin{array}{l}\text { Expan- } \\
\text { sion }{ }^{3} \\
\left(25 \mathrm{C}^{\text {to }}\right. \\
\text { critical } \\
\text { tempera- } \\
\text { ture) }\end{array}$} & \multirow{2}{*}{$\begin{array}{c}\text { Softening } \\
\text { temperature }\end{array}$} & \multirow{2}{*}{$\begin{array}{l}\text { Expansion } \\
\text { (25 C to } \\
\text { softening } \\
\text { tempera- } \\
\text { ture) }\end{array}$} \\
\hline & $\mathrm{SiO}_{2}$ & $\mathrm{Na}_{2} \mathrm{O}$ & $\mathrm{CaO}$ & & & & & \\
\hline $\begin{array}{l}1(3) \\
2(6) \\
3(8) \\
4(12) \\
5(14)\end{array}$ & $\begin{array}{c}\text { Percent } \\
52.15 \\
54.14 \\
57.45 \\
59.97 \\
62.86\end{array}$ & $\begin{array}{c}\text { Percent } \\
47.85 \\
45.86 \\
42.55 \\
40.03 \\
37.14\end{array}$ & $\begin{array}{l}\text { Percent } \\
- \\
-\end{array}$ & $\begin{array}{l}\text { Microns } \\
\text { per cm } \\
81(+2) \\
76(0) \\
73(+2) \\
70(+2) \\
66(+2)\end{array}$ & $\begin{array}{c}{ }^{\circ} \mathrm{C} \\
426(+2) \\
428(-5) \\
442(+2) \\
445(-2)\end{array}$ & $\begin{array}{l}\begin{array}{l}\text { Microns } \\
\text { per cm }\end{array} \\
84(-1) \\
81(-1) \\
80(0) \\
76(0)\end{array}$ & $\begin{array}{c}{ }^{\circ} C \\
440(0) \\
450(+3) \\
460(+3) \\
460(-5) \\
470(-4)\end{array}$ & $\begin{array}{l}\text { Microns } \\
\text { per cm } \\
95(+2) \\
94(+1) \\
89(-1) \\
85(-2) \\
82(-2)\end{array}$ \\
\hline $\begin{array}{r}6(16) \\
7(19) \\
8(20) \\
9(21) \\
10(22)\end{array}$ & $\begin{array}{l}65.30 \\
67.14 \\
69.65 \\
70.21 \\
70.44\end{array}$ & $\begin{array}{l}34.70 \\
32.86 \\
30.35 \\
29.79 \\
29.56\end{array}$ & & $\begin{array}{l}61(+1) \\
58(0) \\
55(+2) \\
55(+2) \\
55(+3)\end{array}$ & $\begin{array}{l}457(+4) \\
460(+2) \\
470(+5) \\
470(+3) \\
467(0)\end{array}$ & $\begin{array}{l}73(0) \\
69(-2) \\
67(0) \\
68(+2) \\
68(+2)\end{array}$ & $\begin{array}{l}490(+7) \\
490(+2) \\
505(+9) \\
500(+2) \\
500(+1)\end{array}$ & $\begin{array}{l}80(-1) \\
77(-2) \\
76(0) \\
76(+1) \\
77(+2)\end{array}$ \\
\hline $\begin{array}{l}11(23) \\
12(28) \\
13(29) \\
14(31) \\
15(32)\end{array}$ & $\begin{array}{l}72.15 \\
76.60 \\
76.65 \\
77.85 \\
78.61\end{array}$ & $\begin{array}{l}27.85 \\
23.40 \\
23.35 \\
22.15 \\
21.39\end{array}$ & & $\begin{array}{l}51(0) \\
44(+1) \\
44(+1) \\
41(0) \\
40(0)\end{array}$ & $\begin{array}{l}473(+2) \\
480(-3) \\
485(+2) \\
486(-1) \\
490(+2)\end{array}$ & $\begin{array}{l}64(0) \\
56(0) \\
58(0) \\
53(-1) \\
53(0)\end{array}$ & $\begin{array}{l}500(-4) \\
510(-8) \\
510(-8) \\
525(+3) \\
520(-4)\end{array}$ & $\begin{array}{l}72(0) \\
63(-1) \\
65(0) \\
63(0) \\
60(-1)\end{array}$ \\
\hline $\begin{array}{l}16(33) \\
17 \\
18 \\
19(34) \\
420(38)\end{array}$ & $\begin{array}{c}79.73 \\
80.04 \\
82.72 \\
82.76 \\
100\end{array}$ & $\begin{array}{l}20.27 \\
19.96 \\
17.28 \\
17.24 \\
----\end{array}$ & & $\begin{array}{l}38(0) \\
38(0) \\
34(0) \\
34(0)\end{array}$ & $\begin{array}{l}489(-1) \\
492(+5) \\
495(-5) \\
500(0) \\
1,020\end{array}$ & $\begin{array}{l}50(-1) \\
50(0) \\
45(0) \\
45(0) \\
5\end{array}$ & $\begin{array}{c}530(+2) \\
525(-4) \\
540(+2) \\
550(+12) \\
1,140\end{array}$ & $\begin{array}{l}57(-2) \\
55(-3) \\
53(0) \\
52(-1) \\
6\end{array}$ \\
\hline $\begin{array}{l}21 \\
22(41) \\
23(42) \\
24 \\
25(43)\end{array}$ & $\begin{array}{l}52.20 \\
54.37 \\
56.20 \\
56.34 \\
56.76\end{array}$ & $\begin{array}{l}27.97 \\
32.85 \\
34.00 \\
23.91 \\
37.48\end{array}$ & $\begin{array}{r}19.83 \\
12.78 \\
9.80 \\
19.75 \\
5.76\end{array}$ & $\begin{array}{l}59(-1) \\
62(-3) \\
67(0) \\
51(-1) \\
67(0)\end{array}$ & $\begin{array}{l}498(-7) \\
477(+1) \\
470(+1) \\
517(-10) \\
444(-9)\end{array}$ & $\begin{array}{l}80(0) \\
79(-2) \\
84(+5) \\
73(-3) \\
77(-4)\end{array}$ & $\begin{array}{l}535(+3) \\
505(-3) \\
495(-6) \\
550(-4) \\
480(-4)\end{array}$ & $\begin{array}{l}90(0) \\
83(-6) \\
90(+2) \\
80(-6) \\
87(-3)\end{array}$ \\
\hline $\begin{array}{l}26(44) \\
27 \\
28(45) \\
29 \\
30(46)\end{array}$ & $\begin{array}{l}58.41 \\
60.05 \\
60.32 \\
62.93 \\
63.34\end{array}$ & $\begin{array}{l}38.54 \\
19.79 \\
24.50 \\
17.39 \\
24.39\end{array}$ & \begin{tabular}{r|r}
3.05 \\
20.16 \\
15.18 \\
19.68 \\
12.27
\end{tabular} & $\begin{array}{l}68(+1) \\
49(+1) \\
52(0) \\
43(-1) \\
52(+1)\end{array}$ & $\begin{array}{l}437(-9) \\
548(-2) \\
520(+1) \\
568(+3) \\
518(+5)\end{array}$ & $\begin{array}{l}77(-2) \\
74(+3) \\
74(+1) \\
69(0) \\
74(+2)\end{array}$ & $\begin{array}{l}473(-3) \\
580(+1) \\
547(-3) \\
595(-1) \\
550(+2)\end{array}$ & $\begin{array}{l}88(-2) \\
81(-1) \\
79(-3) \\
77(-1) \\
81(0)\end{array}$ \\
\hline $\begin{array}{l}31(47) \\
32(48) \\
33(49) \\
34 \\
35\end{array}$ & $\begin{array}{l}64.14 \\
64.70 \\
65.71 \\
66.05 \\
66.12\end{array}$ & $\begin{array}{l}21.22 \\
26.84 \\
28.79 \\
17.92 \\
13.97\end{array}$ & $\begin{array}{r}14.64 \\
8.46 \\
5.50 \\
16.03 \\
19.91\end{array}$ & $\begin{array}{l}47(0) \\
52(0) \\
53(0) \\
44(+1) \\
40(+2)\end{array}$ & $\begin{array}{l}530(-5) \\
493(-2) \\
493(+12) \\
563(+6) \\
587(0)\end{array}$ & $\begin{array}{l}69(0) \\
71(+1) \\
72(+2) \\
69(+3) \\
67(+1)\end{array}$ & $\begin{array}{l}570(+1) \\
530(-2) \\
515(-1) \\
595(+5) \\
625(+3)\end{array}$ & $\begin{array}{l}76(-2) \\
81(+2) \\
79(0) \\
78(+2) \\
77(+2)\end{array}$ \\
\hline $\begin{array}{l}36(50) \\
37 \\
38(51) \\
39(52) \\
40\end{array}$ & $\begin{array}{l}66.47 \\
67.23 \\
67.30 \\
67.98 \\
70.12\end{array}$ & $\begin{array}{l}21.74 \\
11.62 \\
29.43 \\
22.50 \\
15.03\end{array}$ & $\begin{array}{r}11.79 \\
21.15 \\
3.27 \\
9.52 \\
14.85\end{array}$ & $\begin{array}{l}48(+2) \\
37(+2) \\
53(0) \\
47(0) \\
39(+1)\end{array}$ & $\begin{array}{l}522(-4) \\
601(-2) \\
480(+7) \\
518(+1) \\
567(-9)\end{array}$ & $\begin{array}{l}72(+6) \\
64(-1) \\
69(-1) \\
68(+2) \\
63(+1)\end{array}$ & $\begin{array}{l}560(-2) \\
645(+1) \\
515(+5) \\
560(+6) \\
610(-1)\end{array}$ & $\begin{array}{l}84(+8) \\
75(0) \\
78(+1) \\
82(+7) \\
73(+2)\end{array}$ \\
\hline $\begin{array}{l}41(53) \\
42( \\
43(54) \\
44(55) \\
45(56)\end{array}$ & $\begin{array}{l}70.50 \\
71.70 \\
72.08 \\
72.61 \\
74.09\end{array}$ & $\begin{array}{l}23.00 \\
12.10 \\
14.21 \\
24.24 \\
15.23\end{array}$ & $\begin{array}{r}6.50 \\
16.20 \\
13.71 \\
3.15 \\
10.68\end{array}$ & $\begin{array}{l}45(-1) \\
35(+1) \\
36(0) \\
46(+1) \\
36(0)\end{array}$ & $\begin{array}{l}506(0) \\
598(-2) \\
571(-8) \\
490(-2) \\
555(-8)\end{array}$ & $\begin{array}{l}62(-1) \\
60(0) \\
59(-1) \\
61(0) \\
57(-2)\end{array}$ & $\begin{array}{l}545(-1) \\
630(-6) \\
615(0) \\
530(+1) \\
600(-1)\end{array}$ & $\begin{array}{l}73(0) \\
65(-3) \\
68(-1) \\
72(+1) \\
68(+1)\end{array}$ \\
\hline $\begin{array}{l}46(57) \\
47(58) \\
48( \\
49(59) \\
50(60)\end{array}$ & $\begin{array}{l}74.69 \\
75.48 \\
78.56 \\
78.77 \\
80.59\end{array}$ & $\begin{array}{l}12.28 \\
15.26 \\
18.45 \\
16.33 \\
16.17\end{array}$ & $\begin{array}{r}13.03 \\
9.26 \\
2.99 \\
4.90 \\
3.24\end{array}$ & $\begin{array}{l}33(-1) \\
36(0) \\
38(+1) \\
34(-1) \\
32(-2)\end{array}$ & $\begin{array}{l}589(-4) \\
553(-5) \\
504(-7) \\
523(-8) \\
505(-17)\end{array}$ & $\begin{array}{l}57(0) \\
54(-3) \\
52(-1) \\
51(-1) \\
43(-6)\end{array}$ & $\begin{array}{l}627(-4) \\
600(+3) \\
545(-8) \\
565(-9) \\
560(-1)\end{array}$ & $\begin{array}{l}66(-1) \\
65(0) \\
60(0) \\
61(+1) \\
55(-4)\end{array}$ \\
\hline
\end{tabular}

1 Figures in parentheses in this column are the numbers of the corresponding glasses in the report cited in footnote 2 of the text. Additional glasses made for this study have only 1 number.

2 The methods of analyses of these glasses are discussed in the reports cited in footnote 1 of the text.

3 Figures in parentheses in these columns are the algebraic differences, to the nearest whole number, between the observed values and those obtained by computation or from the graphs in figures 1, 2, or 3; + difierences indicate observed values greater than computed values.

4 The data on fused quartz (not published) were furnished by G. E. Merritt and are the average from several samples which were neither made nor analyzed at this Bureau. 

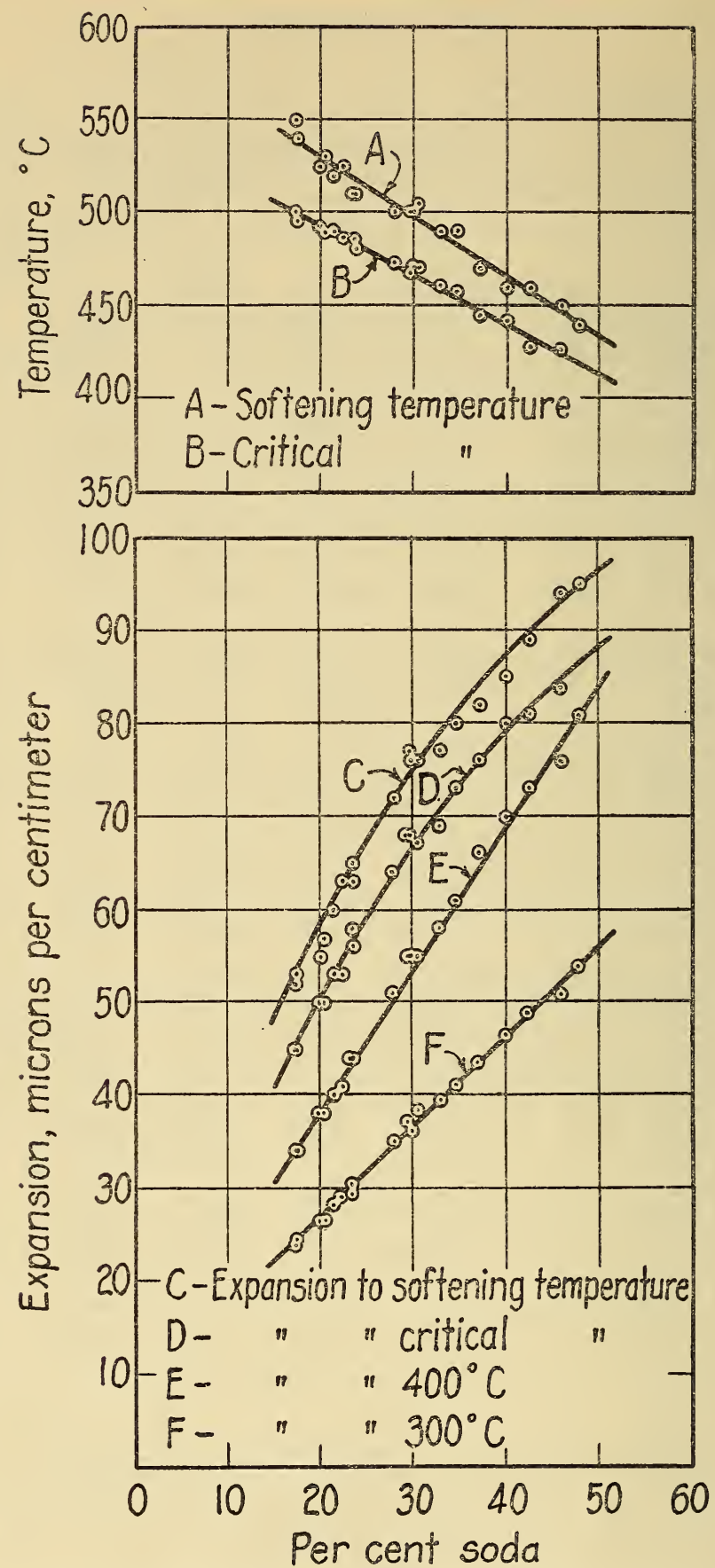

FIGURE 1.-Diagram showing relations between composition, critical and softening temperatures, and linear expansions of some soda-silica glasses. 
practically constant and equal to the rate between 25 and $100 \mathrm{C}$. The maximum "correction" was 2 microns, the average being less than 1 micron.

The critical and softening temperatures of the soda-silica glasses and corresponding expansions (all obtained as described above) and also the expansions to 300 and $400 \mathrm{C}$ are plotted in figure 1 against the soda content.

If the expansions from $25 \mathrm{C}$ to any specific temperature, $T$, below the approximate critical temperature are considered, it was found that these expansions can be computed from equations of the familiar form $E=a A+b B+c C$, in which $E$ is the linear expansion in microns per centimeter; $A, B$, and $C$ are the percentages of silica, soda, and lime, respectively, and $a, b$, and $c$ are constants determined for a given temperature. The values of these constants for each interval $25 \mathrm{C}$ to $T$ as $T$ was increased by $50 \mathrm{C}$ steps from 50 to $450 \mathrm{C}$ were determined by making independent solutions by the method of least squares, and by using the expansion values of the various glasses as read from the individual expansion curves corrected to $25 \mathrm{C}$. The soda-silica and soda-lime-silica glasses were treated separately. In this way it was found that $a, b$, and $c$ are functions of temperature, fitting very closely the equations:

$$
\begin{aligned}
& a=0.00036 t-0.00000036 t^{2} \\
& b=0.00245 t+0.0000046 t^{2} \\
& c=0.00116 t+0.0000010 t^{2}
\end{aligned}
$$

where $t=T-25 \mathrm{C}$. The coefficients of $t$ and $t^{2}$ for $a, b$, and $c$, respectively, were obtained by the method of least squares, using the various values of $a, b$, and $c$, determined as indicated above, for the different temperature intervals. The numerical values shown are those obtained from the soda-lime-silica glasses only. Although a solution of the soda-silica glasses gave only slightly different equations for $a$ and $b$, less weight should be attached to them because, as previously stated, they are based on the first determinations (second determinations being used for the lime-glass data). For the purpose of evaluating the constants, no temperature above $450 \mathrm{C}$ was used, since many of the glasses are approaching their critical temperatures at this point, and hence any solution involving data above $450 \mathrm{C}$ would be of doubtful value. The equations were found, however, to be adequate within about $50 \mathrm{C}$ of the critical temperature for any glass, a few such temperatures being as high as $600 \mathrm{C}$. The average deviation increases with temperature, being about 0.3 micron at $50 \mathrm{C}$ and about 1.5 microns at $550 \mathrm{C}$, (the corresponding maximum deviations being 1 and 3 microns respectively) and at no temperature is there a noticeable systematic deviation, as long as no glass is considered after it comes within $50 \mathrm{C}$ of its critical temperature.

Graphs $\mathrm{E}$ and $\mathrm{F}$ in figure 1 show observed linear expansions of the soda-silica glasses at 300 and $400 \mathrm{C}$, and also the lines obtained by solving the equations given above for $E, a$, and $b$ being evaluated at these temperatures.

Based on the data obtained, several different kinds of empirical equations for computing the critical and softening temperatures and the expansions from $25 \mathrm{C}$ to these temperatures for a given glass in either series can be devised. The following empirical relations were used, however, to compute the residuals presented along with the last 
four columns in table 1 . For both the critical and softening temperatures

$$
T=d+e(B+C)+p\left(\frac{C}{B}\right)+q\left(\frac{C}{B}\right)^{2}
$$

For the expansion to both temperatures

$$
E=f+g B+h B^{2}+r\left(\frac{C}{B}\right)^{n}
$$

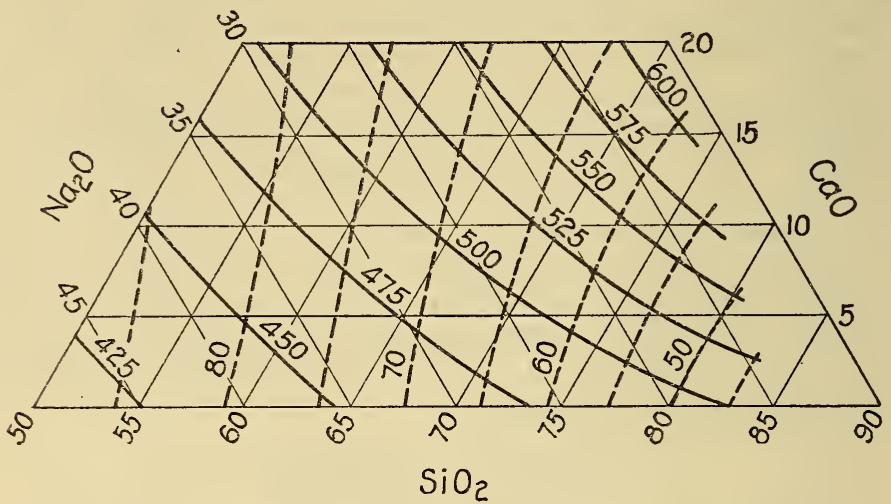

FIGURE 2.-Diagram showing relations between composition of some soda-limesilica glasses and critical temperatures (solid lines) and also linear expansions (broken lines) to those temperatures. Temperatures are given in $C$ and expansions in microns per $\mathrm{cm}$.

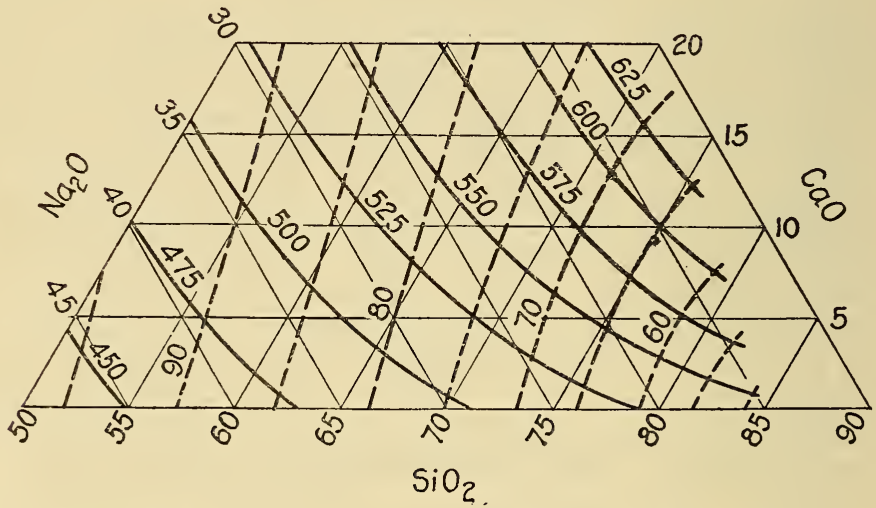

FIGURE 3.-Diagram showing relations between composition of some soda-limesilica glasses and softening temperatures (solid lines) and also linear expansions (broken lines) to those temperatures. Temperatures are given in $C$ and expansions in microns per $\mathrm{cm}$.

In these equations $B$ and $C$ are the percentages of soda and lime, respectively, and $d, e, f, g, h, p, q, r$, and $n$ are constants having somewhat different values in computing the data relating to the critical and softening temperatures. For example, $p, q, f$, and $r$ remain practically unchanged, while $h$, the coefficient of $B^{2}$, changes approximately 30 percent. Actual use of numerical values for these constants was not made, however, since a graphic method based on the above relations 
was found to be both simpler and adequate for determining both the differences (see table) and the lines (see figs. 2 and 3), which show how the composition of these glasses may vary without changing one of the following: The critical temperature, the softening temperature ${ }^{4}$ or the expansion to one of these.

\section{REPRODUCIBILITY AND ACCURACY OF RESULTS}

Generally any one glass gave reproducible expansion measurements within 1 or 2 microns and temperature measurements within 5 degrees if the same specimens were used for a second series of measurements. The average difference between duplicate measurements of the expansions to the softening points, of the 34 glasses on which two tests were made, was 2 microns; measurements on 23 of the glasses varied 2 microns or less, on 5 glasses the difference was 3 microns and on the remaining 6 the average was 6 , the maximum being 8 microns.

To demonstrate the effect of the shape of the sample on these results, two sets of specimens were prepared. For one of these the truncated cones were very stocky, that is they were relatively broad at the base, with only a slight taper and relatively flat, though rounded, at the top. For the other, the specimens had a smaller base and the cone was reduced to the equivalent of a very slender rod with a rather sharp point at the top. As might be expected, the critical temperature and expansion to that temperature were not significantly affected by shape, but the softening temperature and expansion of the slender specimen were $595 \mathrm{C}$ and 79 microns, while similar values for the stocky specimen were $610 \mathrm{C}$ and 91 microns, respectively. Hence under these conditions it is evident that one might obtain a difference of $15 \mathrm{C}$ in softening temperature and 12 microns in expansion, depending upon the shape of the specimens used. No such extreme differences in shape existed between the specimens used in determining the data presented in table 1 , but there were certainly some differences and these would account to some extent for such irregularities as occur in the softening temperatures and corresponding expansions. As a matter of fact, the unavoidable differences in shape of the points of the specimen which are in contact with the interferometer plates have ordinarily more significance than the shape of the body of the specimen and it is probably the relatively rapid flattening of these points during the first test which causes a portion of the differences between first and second tests.

Comparison of the data on the soda-silica glasses reported in this paper with that of Turner and Winks ${ }^{5}$ shows certain differences. For instance, their data on any one glass plot as a comparatively straight line up to the critical temperature, while the expansion values obtained at different temperatures in the present work plot more definitely concave upward. Also, their expansions for the lower temperature ranges are somewhat (approximately 2 microns) higher, although their softening temperatures (called annealing temperatures, $A_{t}$ ) and the expansions to these temperatures are somewhat lower than those obtained in the present case. Their softening temperatures, for example, conform reasonably well to a straight line

\footnotetext{
4 For practical purposes, and also within the limits of accuracy of the data, it can be stated that the critical temperatures are approximately 93.5 percent of the softening temperatures and that the expansions to the critical temperatures are approximately 88.5 percent of the expansions to the softening temperatures. However, different conditions of annealing may materially change the latter figure.

5 Jour. Soc. Glass Tech., vol. 14, p. 110, 1930.
} 
about $7^{\circ} \mathrm{C}$ lower than curve $\mathrm{A}$ in figure 1 . Their temperatures, designated by " $C_{t}$," are also lower than the critical temperatures reported in this paper and do not agree with them except in a general way.

These differences are not surprising when one considers that the data were obtained by two distinctly different methods of measurement which involved the use of specimens of decidedly different length ( $5 \mathrm{~mm}$ as compared with $100 \mathrm{~mm}$ used by Turner and Winks); also, differences in the size of furnaces used and the consequent difficulty of obtaining uniform and reproducible temperature distribution should not be overlooked. It is thought that expansion measurements made by the interferometer method are very satisfactory for obtaining comparative data, because small samples can be used and also because no standard material of known thermal expansion is necessary for calibrating the apparatus.

\section{ANNEALING RANGE}

The proper annealing of glass is a problem which confronts every glass manufacturer and much has been written on the subject. The most noteworthy contribution is that by Adams and Williamson, ${ }^{6}$ who point out the desirability of using different annealing temperatures for the same kind of glass, the actual temperatures used being dependent on the thickness of the piece to be annealed.

The annealing range for most commercial glassware lies between the critical and softening temperatures, but since the time required for annealing increases as the annealing temperature decreases, the optimum annealing temperature for any given piece will be as close to the softening temperature of the glass from which it is made as is consistent with the cooling rate that will be obtained in the lehr. Since the critical and softening temperatures of glasses of the soda-lime series may be read from figures 2 and 3 , the approximate temperature ranges in which such glasses can be annealed may be readily estimated, but in this work no consideration has been given to the time required for annealing at various temperatures in the annealing range.?

\section{SUMMARY}

The data and graphs in this paper, based on 19 soda-silica and 30 soda-lime-silica glasses, show the changes in thermal expansion, critical temperature, softening temperature, and annealing range of soda-lime-silica glasses with changes in composition in the range between approximately 12 and 50 percent soda, 0 and 20 percent lime, and 50 and 80 percent silica.

Washington, January 17, 1934.

\footnotetext{
6 Jour. Frank. Institute, vol. 190, pp. 597-631 and 835-870, 1920.

7 For information on time-temperature annealing effects and schedules, see reference cited in footnote 6 . See also Tool, A. Q., and Valasek, J., B.S. Scientific Paper 358, 1919; and Finn, A. N., Jour. Am. Cer. Soc., vol. 9, no. 8, p. 493, 1926.
} 